Advances in Research
$\begin{gathered}\text { Alvances in } \\ \text { Researeh }\end{gathered}$
3(6): 558-570, 2015, Article no.AIR.2015.051
ISSN: 2348-0394
SCIENCEDOMAIN international
www.sciencedomain.org

\title{
The Influence of Selected Soil Conservation Practices on Soil Properties and Crop Yieldsin the Usambara Mountains, Tanzania
}

\author{
S. B. Mwango ${ }^{1^{*}}$, B. M. Msanya1, P. W. Mtakwa ${ }^{1}$, D. N. Kimaro ${ }^{2}$ \\ J. Deckers ${ }^{3}$, J. Poesen ${ }^{3}$, I. Nzunda ${ }^{1}$ and S. Ringo ${ }^{1}$ \\ ${ }^{1}$ Department of Soil Science, Sokoine University of Agriculture, P.O. Box 3008 Chuo Kikuu, Morogoro, \\ Tanzania. \\ ${ }^{2}$ Department of Agricultural Engineering and Land Planning, Sokoine University of Agriculture, \\ P.O. Box 3003 Chuo Kikuu, Morogoro, Tanzania. \\ ${ }^{3}$ Department of Earth and Environmental Sciences, KU Leuven, Celestijnenlaan 200 E, B-3001, \\ Heverlee, Belgium.
}

\section{Authors' contributions}

This work was carried out in collaboration between all authors. Author SBM designed the study, wrote the protocol, conducted field work, performed statistical analysis and wrote the first draft of the manuscript. Author BMM designed the study, conducted field work, managed the literature searches and edited drafts. Author PWM designed the study, conducted field work and edited drafts. Authors $D N K, J D$ and JP designed the study and edited drafts. Authors IN and SR conducted field work. All authors read and approved the final manuscript.

Article Information

DOI: $10.9734 / A I R / 2015 / 13647$

Editor(s):

(1) Marco Trevisan, Faculty of Agricultural Sciences, Institute of Agricultural and Environmental Chemistry, Catholic University of the Sacred Heart, Italy. Reviewers:

(1) Rusu Teodor, University of Agricultural Sciences and Veterinary Medicine Cluj, 3-5 Manastur Street, 400372, Cluj-Napoca, Romania.

(2) Godsteven Peter Maro, TaCRI, Lyamungu P.O. Box 3004, Moshi, Tanzania. (3) Anonymous, São Paulo State University, Brazil. Complete Peer review History: http://www.sciencedomain.org/review-history.php?iid=758\&id=31\&aid=7114

Original Research Article

Received 26 $6^{\text {th }}$ August 2014

Accepted $5^{\text {th }}$ October 2014 Published $8^{\text {th }}$ December 2014

\begin{abstract}
The Usambara Mountains in Tanzania are severely affected by soil erosion which has led to deterioration of soil properties and reduced crop productivity. Indigenous soil erosion control measures such as miraba which are widely practised in the area have yielded little success. Field plot experiments were laid down in Majulai and Migambo villages from 2011 - 2014 on typical soils of the
\end{abstract}

${ }^{*}$ Corresponding author: E-mail: sibawaymwango@yahoo.com; 
area (Acrisols). The aim was to single out soil properties developed under the studied soil conservation practices and their impact on crop productivity with reference to maize (Zea mays) and beans (Phaseolus vulgaris). Results showed that total $\mathrm{N}, \mathrm{OC}$, available $\mathrm{P}, \mathrm{Ca}^{2+}, \mathrm{Mg}^{2+}, \mathrm{K}^{+}$and $\mathrm{Ph}$ were powerful $(P=.05)$ attributes that discriminated conservation measures. Magnitudes of the discriminating attributes followed the trend: miraba with Tughutu (Vernonia myriantha) mulching $>$ miraba with Tithonia (Tithonia diversifolia) mulching > miraba sole > cropl and with no 'Soil and Water Conservation' (SWC) measures (control). Contents ofmicro-nutrients did not differ significantly with SWC measures except for $\mathrm{Zn}$ which was significantly $(P=.05)$ lowin the control. Bulk density and available moisture content (AMC) were also strong discriminators of conservation measures. Maize and bean grain yields differed significantly $(P=.05)$ with the trend: miraba with Tughutu $>$ miraba with Tithonia $>$ miraba sole $>$ control in both villages. Crop yields under miraba were a function of $\mathrm{AMC}$ and $\mathrm{pH}\left(\mathrm{R}^{2}=0.71\right)$; $\mathrm{AMC}$, available $\mathrm{P}, \mathrm{Ca}^{2+}$ and $\mathrm{K}^{+}\left(\mathrm{R}^{2}=0.89\right)$ under miraba with Tithonia mulching; AMC, available $\mathrm{P}, \mathrm{Ca}^{2+}$ and $\mathrm{K}^{+}\left(\mathrm{R}^{2}=0.90\right)$ under miraba with Tughutu mulching. These findings imply that miraba with Tughutu mulching had greater potential in improving soil properties and crop yields than miraba with Tithonia mulching and miraba sole.

Keywords: Soil erosion; miraba; Tithonia; Tughutu; maize yields; bean yields.

\section{INTRODUCTION}

The problem of soil erosion is global, and has been reported all over the world to affect agricultural sustainability $[1,2,3]$. For example the Usambara Mountains of Tanzania which are characterized by a high population density of about 120.4 persons $/ \mathrm{km}^{2}$, and practise farming on steep slopes of more than $40 \%$ due to land scarcity, suffer from severe soil degradation by water erosion $[4,5]$. Soil loss, nutrient depletion and reduced capacity of the soil to retain water are major forms of soil degradation in the area. These have led to deterioration of soil properties and reduced crop productivity [6]. Population pressure in the area has led to increased land use intensity and expansion of cultivation of food and cash crops in valleys and sloping land $[4,5]$.

There is a growing concern that land use practices in the Usambara Mountains may not be sustainable because of their detrimental effects on soil properties $[4,7]$. To address the problem of soil degradation by water erosion, Usambara farmers developed indigenous 'Soil and Water Conservation' (SWC) measures such miraba (rectangular grass bound strips that do not necessarily follow contour lines), micro-ridges and stone bunds as integral part of their farming systems, while introduced measures have often been rejected or minimally adopted because they were expensive in terms of money and labour $[9,8]$. Surprisingly however, the indigenous soil erosion control measures implemented in the area have remained poorly documented [8]. Besides, farmers' efforts to conserve the degrading land have yielded very little success, and deterioration of some soil properties are active even in places where SWC measures are practised $[9,4,7,10]$. This is partly due to limited knowledge on the effectiveness of the indigenous SWC practices. Moreover, indigenous SWC measures in the area have been for decades left traditional with little scientific intervention for improvement $[9,10]$.

Indigenous SWC measures have been documented to play a considerable role in controlling soil erosion and improving crop yield. For example, stone bunds in Ethiopia have been reported by Van campenhout et al. [11] to be effective in increasing yields from 632 to $683 \mathrm{~kg}$ $\mathrm{ha}^{-1}$ for cereals, from 501 to $556 \mathrm{~kg} \mathrm{ha}^{-1}$ for Eragrostis tef and from 335 to $351 \mathrm{~kg} \mathrm{ha}^{-1}$ for Cicer arietinum as compared to the situation without stone bunds. Likewise the study by Msita [10] in Usambara Moutains, Tanzania revealed miraba to have some contribution in controlling soil erosion and increased maize yield form 0.7 $\mathrm{Mg} \mathrm{ha}^{-1}$ in cropland with no soil conservation measures to $1.1 \mathrm{Mg} \mathrm{ha}^{-1}$ in farms with miraba.

Although studies on the effectiveness of some introduced SWC technologies on soil erosion control and agricultural productivity have recently been carried out in Western Usambara Mountains [9,7], the contribution of indigenous SWC measures including miraba which is the most preferred in the study area have not fully been investigated $[4,10]$. Even when investigated, not a single study has attempted to explain the linkages that exist between soil properties and crop productivity associated with SWC technologies. Furthermore, land use planners, agricultural managers and extension 
officers need sound information to guide implementation of SWC practices within the context of improved soil properties and maximized crop production; yet, at present such information does not exist.

The study reported here in, was therefore aimed at establishing the linkages between identified soil properties associated with soil conservation practices namely miraba and miraba with various mulching materials with reference to productivity of maize (Zea maize) and beans (Phaseolus vulgaris) under smallholder farming conditions in Usambara Mountains. The objectives of this study were (i) to identify soil properties that discriminate between selected SWC practices (ii) to test whether the identified soil properties correlated with crop yield and (iii) to investigate the relation between the identified soil properties and crop yield.

\section{MATERIALS AND METHODS}

\subsection{Description of the Study Sites}

Migambo and Majulai villages in Western Usambara Mountains, Lushoto District, Tanzania (Fig. 1) are located between $38^{\circ} 15^{\prime}$ to $38^{\circ} 24^{\prime} \mathrm{E}$ and $4^{\circ} 34^{\prime}$ to $4^{\circ} 48^{\prime} \mathrm{S}$. Migambo is humid cold with mean annual air temperature of $12^{\circ} \mathrm{C}-17^{\circ} \mathrm{C}$ and an annual precipitation ranging from $800-2300$ $\mathrm{mm}$. Majulai is dry warm with mean annual air temperature between $16^{\circ} \mathrm{C}$ and $21^{\circ} \mathrm{C}$ and annual precipitation of 500-1700 $\mathrm{mm}$. The annual evapo-transpiration (ETo) as estimated by the local climate estimator software (New_LocClim) [12] ranges from $100 \mathrm{~mm}$ to $145 \mathrm{~mm}$. The Usambara Mountains support a large population density of more than 120.4 persons $/ \mathrm{km}^{2}$ [5]. According to the World Reference Base (WRB) for Soil Resources [13] the soils in Majulai site classified as Chromic Acrisols (Humic, Profondic, Clayic, Cutanic, Colluvic) whereas in Migambo site the soils are Haplic Acrisols (Humic, Profondic, Clayic, Colluvic).

The main land uses include cultivation on slopes and valley bottoms, settlements on depressions, lower ridge summits and slopes and forest reserves on ridge summits and upper slopes. Vegetables such as carrots, onions, tomatoes, cabbages and peas are grown as sole crops in valleys under rain fed or traditional irrigation. Beans are grown mainly during long rains and maize in short rains. Irish potatoes and fruits namely peaches, plums, pears, avocado, and banana are grown on ridge slopes under rain fed mixed farming. Irish potatoes are also grown in valleys as sole or intercropped with maize.

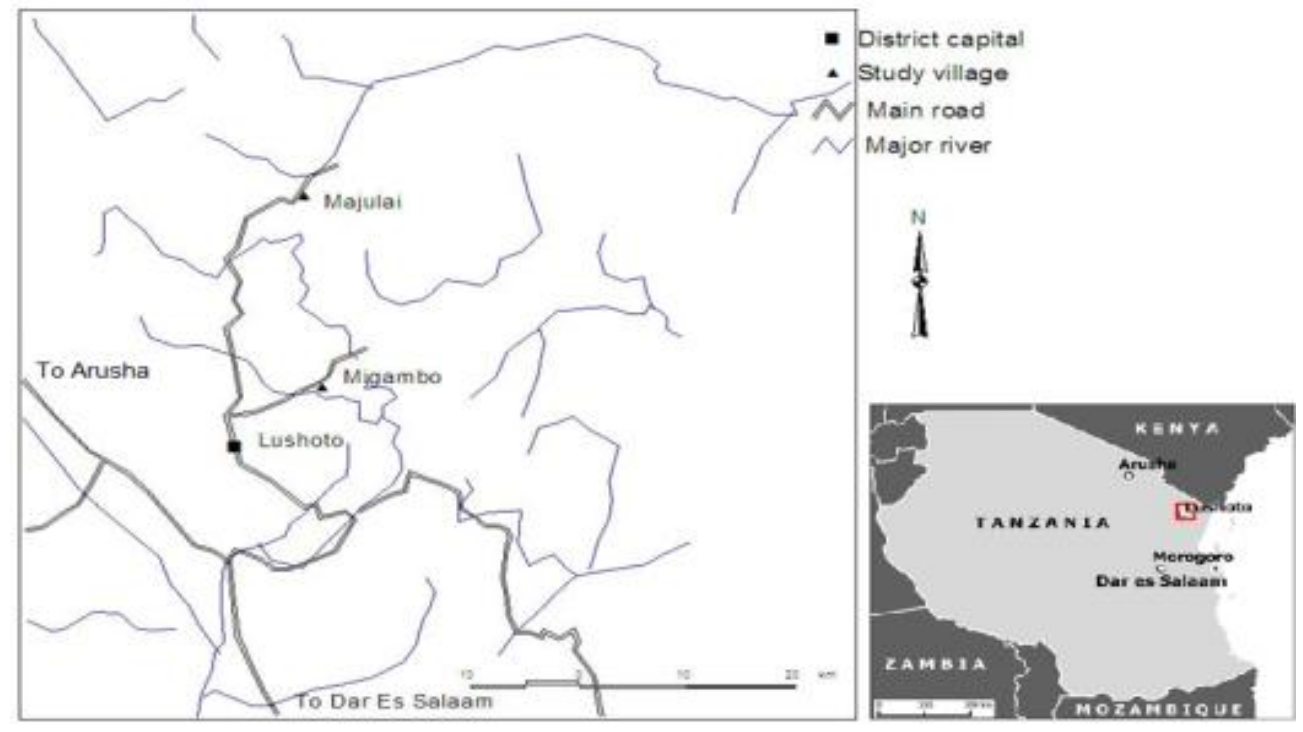

Fig. 1. Location Map of Migambo and Majulai villages, Lushoto District, Tanzania 


\subsection{Establishment of Miraba in Field Plots}

Miraba were established using Napier grass (Pennisetum purpureum) barriers in field plots in April 2011 about nine months before crops were grown. Tillers of Napier grass were planted in single rows at $10 \mathrm{~cm}$ spacing perpendicular to the general slope and were maintained to about $50 \mathrm{~cm}$ wide strips. Napier grass barriers across the slope were spaced $5 \mathrm{~m}$ apart to mimic the recommended maximum effective width of hand made bench terraces [14]. On the other hand, the spacing of Napier grass barriers forming miraba along the slope was set at $3 \mathrm{~m}$ apart.

It has been documented that soil conservation measures such as Fanya Juu (hillside ditches made by throwing excavated soil on the upslope of the ditch, built along contour lines at appropriate intervals depending on slope gradient) and stone bunds tend to progressively form bench terraces when at close spacing $[14,15]$. Moreover, the closer the grass strips are the more effective they become in controlling soil erosion [15]. Progressive bench terrace formation is also possible under miraba when adjusted to appropriate spacing of grass strips. Natural bench terrace formation as a result of miraba implementation is much less expensive compared to mechanical bench terrace construction which is feared by farmers. Bench terraces are highly recommended for use in Usambara Mountains [16,17,9,4].

\subsection{Experimental Design}

Miraba plots $22 \mathrm{~m} \times 3 \mathrm{~m}$ in a randomized complete block design (RCBD) were set in the lower ridge slopes at $50 \%$ slope in Majulai and $45 \%$ slope in Migambo village (Fig. 2). Maize and beans were planted in rotation as test crops in 2012 and 2013/14 rain seasons, where maize was planted during short rains (vuli) and beans during long rains (masika). The treatments included plots with (i) Miraba and planted with maize or beans (MI) (ii) Miraba with Tithonia mulching and planted with maize or beans (MITH) (iii) Miraba with Tughutu mulching and planted with maize or beans (MITG) (iv) No SWC measures (CO) (Control) and planted with maize or beans, all replicated three times.

\subsection{Mulching Materials}

Mulching materials used included the leaves of Tithonia diversifolia (Alizeti Pori) and Vernonia myriantha (Tughutu) in both villages. The mulch was applied under miraba two weeks after crops germinated at the rate of $3.6 \mathrm{Mg} \mathrm{ha}^{-1}$ dry weight. These shrubs were chosen as mulches because the plants are readily available in the area and have been documented to contain appreciable amounts of N, P and K [18,6]. Samples from each mulching material were collected for determination of total $\mathrm{N}$, available $\mathrm{P}, \mathrm{K}^{+}, \mathrm{Mg}^{2+}$, $\mathrm{Ca}^{2+}$ and $\mathrm{Na}^{+}$.

\subsection{Determination of Soil Chemical and Physical Properties}

The impact of SWC measures on soil chemical and physical properties was determined by taking composite topsoil samples $(0-30 \mathrm{~cm}$ depth) from each treatment for the analysis of $\mathrm{pH}, \mathrm{OC}$, total $\mathrm{N}$, available $\mathrm{P}, \mathrm{K}^{+}, \mathrm{Ca}^{2+}, \mathrm{Mg}^{2+}, \mathrm{Na}^{+}$, $\mathrm{Fe}, \mathrm{Cu}, \mathrm{Zn}, \mathrm{Mn}$ and soil texture.

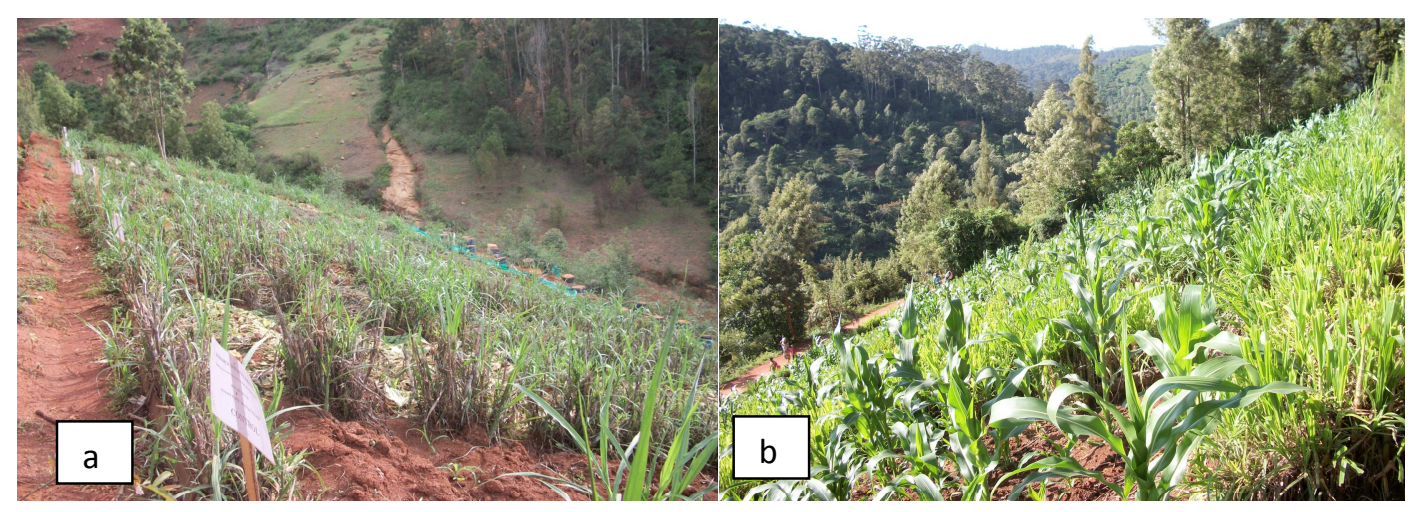

Fig. 2. a) Majulai experimental plots b) Migambo experimental plots with maize crop 
Undisturbed core soil samples were also collected from $0-5 \mathrm{~cm}$ depth for bulk density and available moisture content determination. Soil samples were collected after every cropping season i.e. long rains and short rains from 2012 to $2013 / 14$.In each runoff experimental site a representative soil profile was excavated and described, and soil samples collected from each horizon for pedological characterisation. Undisturbed core soil samples were taken from $0-5 \mathrm{~cm}, 45-50 \mathrm{~cm}$ and $95-100 \mathrm{~cm}$ soil depths by Kopecky's core rings $\left(100 \mathrm{~cm}^{3}\right)$ for bulk density and available moisture determination for further characterization of the representative soil profiles. The soil profiles were classified to tier-2 according to WRB for Soil Resources [13].

\subsection{Crop Yield Determination}

Maize (Zea mays) variety PANNAR 67 and beans (Phaseolus vulgaris) Kilombero variety were planted in runoff plots during the 2012 and 2013/14 rainy seasons with maize in short rains (vuli) and beans during the long rains (masika). The spacing was $75 \mathrm{~cm} \times 30 \mathrm{~cm}$ for maize and 50 $\mathrm{cm} \times 25 \mathrm{~cm}$ for beans. Beans were always planted three weeks before maize was harvested in Migambo and two weeks in Majulai village. Farmyard manure with $0.6 \% \mathrm{~N}, 0.4 \% \mathrm{P}, 0.5 \% \mathrm{~K}$ and $15 \%$ OC was basal and spot applied at the rate of $3.6 \mathrm{Mg} \mathrm{ha}^{-1}$ air-dry weight, DAP 18: 46: 0 NPK ratio and Urea $46 \% \mathrm{~N}$ were applied at the rate of $80 \mathrm{~kg} \mathrm{ha}^{-1}$, but Urea was not applied for beans. At maturity maize and bean grains were harvested and dried to about $13 \%$ moisture content.

\subsection{Soil and Plant Samples Analysis}

Soil analysis was done following Moberg's Laboratory Manual [19]. Organic carbon (OC) was measured using the dichromate oxidation method, total nitrogen (TN) by Kjeldahl method, available phosphorus (Bray-I), exchangeable bases $\left(\mathrm{Ca}^{2+}\right.$ and $\left.\mathrm{Mg}^{2+}\right)$ by atomic absorption spectrophotometer, exchangeable $\mathrm{Na}^{+}$and $\mathrm{K}^{+}$by flame photometer and $\mathrm{pH}_{\text {water }}$ by normal laboratory $\mathrm{pH}$ meter. The available $\mathrm{Fe}, \mathrm{Mn}, \mathrm{Zn}$ and $\mathrm{Cu}$ were extracted using buffered DTPA (Diethylenetriaminepentaacetic acid) method and the DTPA extract was analysed in an Atomic Absorption Spectrophotometer (AAS). Soil texture was determined by Hydrometer method. Bulk density was determined by oven drying and weighing method. Soil moisture retention characteristics were studied using sand kaolin box for low suction values and pressure plate apparatus for higher suction values [20].

\subsection{Statistical Analysis}

Bartlett's test for homogeneity of variance was conducted to test data normality using Gen Stat software [21]. All data were subjected to Analysis of Variance (ANOVA). GenStat statistical analysis software [21] was used for the analysis and significant differences were tested by the Least Significant Difference $\left(\mathrm{LSD}_{0.05}\right)$. Correlation and multiple linear regressions were performed using Minitab software [22] to determine the relationship between soil properties and crop yield under the studied SWC measures.

\section{RESULTS AND DISCUSSION}

\subsection{Selected Chemical Properties of Mulching Materials}

Chemical properties of mulching materials are presented in (Table 1). It can clearly be seen that Tughutu had higher nutrient contents than Tithonia (Table 1). This situation is also supported by other researchers [18] who also found higher NPK contents in Tughutu than in Tithonia shrub.

Table 1. Chemical properties of mulching materials and farm yard manure applied in Majulai and Migambo villages

\begin{tabular}{lllllll}
\hline Mulching & \multicolumn{6}{c}{ Plant nutrients content \% } \\
\cline { 2 - 7 } materials & $\mathbf{N}$ & $\mathbf{P}$ & $\mathbf{K}$ & $\mathbf{C a}$ & $\mathbf{M g}$ & $\mathbf{N a}$ \\
\hline Tithonia & 3.3 & 0.3 & 6.1 & 1.2 & 0.7 & 0.04 \\
Tughutu & 3.6 & 0.3 & 6.3 & 1.4 & 0.9 & 0.04 \\
Farm yard & 1.7 & 0.4 & 1.9 & 0.9 & 0.6 & 0.07 \\
manure & & & & & & \\
\hline
\end{tabular}

\subsection{The Influence of SWC Measures on Selected Soil Physico-chemical Properties}

Variability of soil chemical and physical properties between SWC measures are presented in Tables $2 \& 3$. Considering the soil chemical properties in relation to the SWC measures, most of the properties were significantly $(P=.05)$ different between treatments. The differences can be explained by the influences of the SWC measures applied. It was revealed in both villages that the contents of all studied macro nutrients followed the trend 
that: miraba with Tughutu mulching > miraba with Tithonia mulching $>$ miraba sole $>$ cropl and with no SWC measures (Table 2) except for $\mathrm{Na}^{+}$ which did not significantly $(P=.05)$ differ. Similarly $\mathrm{pH}$ followed the same trend. It was therefore concluded that total $\mathrm{N}, \mathrm{OC}, \mathrm{P}, \mathrm{Ca}^{2+}$, $\mathrm{Mg}^{2+}, \mathrm{K}^{+}$and $\mathrm{pH}$ were powerful attributes that differentiated SWC measures. Studies by Tenge and Kyaruzi $[9,7]$ revealed similar observations where terracing such as bench and Fanya Juu terraces effectively control runoff and soil losses, thus improving soil physical and chemical properties in Usambara Mountains. The higher $\mathrm{pH}$ and macro nutrient status under miraba with Tughutu mulching than under miraba with Tithonia mulching can be explained by the higher nutrient contents of Tughutu as compared with Tithonia mulching material (Table 1). The higher NPK contents in Tughutu than in Tithonia shrub was also reported by Wickama and Mowo [18]. It is also well known that exchangeable bases have strong positive correlation with soil $\mathrm{pH}[23,24]$. In the case of micro nutrients, it was found that there were no significant $(P=.05)$ differences between SWC measures except for $\mathrm{Zn}$ which was significantly low under cropl and with no SWC measures. Therefore $\mathrm{Zn}$ was spotted as the best micronutrient differentiating SWC measures. These differences can be explained by the influences of the tested SWC measures. Kyaruzi [7] in Usambara Mountains, also reported bench terraces and grass strips to have an influence on soil chemical properties such as $\mathrm{pH}$, total $\mathrm{N}, \mathrm{OC}, \mathrm{CEC}, \mathrm{Ca}^{2+}$ and $\mathrm{Mg}^{2+}$ when compared to control. Similar observations were reported by Tenge [9] and Wickama et al. [25] in Usambara Mountains, where soil conservations measures suchas bench terraces, Fanya Juu terraces and grass strips were found to have a big influence on soil chemical and physical properties as compared with cropland with no SWC measures.

On the other hand soil physical properties were significantly $(P=.05)$ different between SWC measures except for soil texture which did not differ (Table 3 ). The available moisture contents (AMC) were higher under miraba with mulching than under miraba sole and cropland with no SWC measures. Bulk density (BD) values were significantly lower under miraba with mulching than under miraba sole and cropland with no SWC measures. Thus AMC and BD were powerful soil physical properties that discriminated SWC measures. The higher AMC and lower bulk density under miraba with mulching can be explained by the increased organic carbon contents due to the application of mulches (Tables $2 \& 3$ ). It has been established that the higher the organic carbon contents in the soil the lower the bulk density while also the higher the capacity of the soil to retain moisture available to plants [26].

Table 2. The influence of the studied SWC practices on soil chemical properties

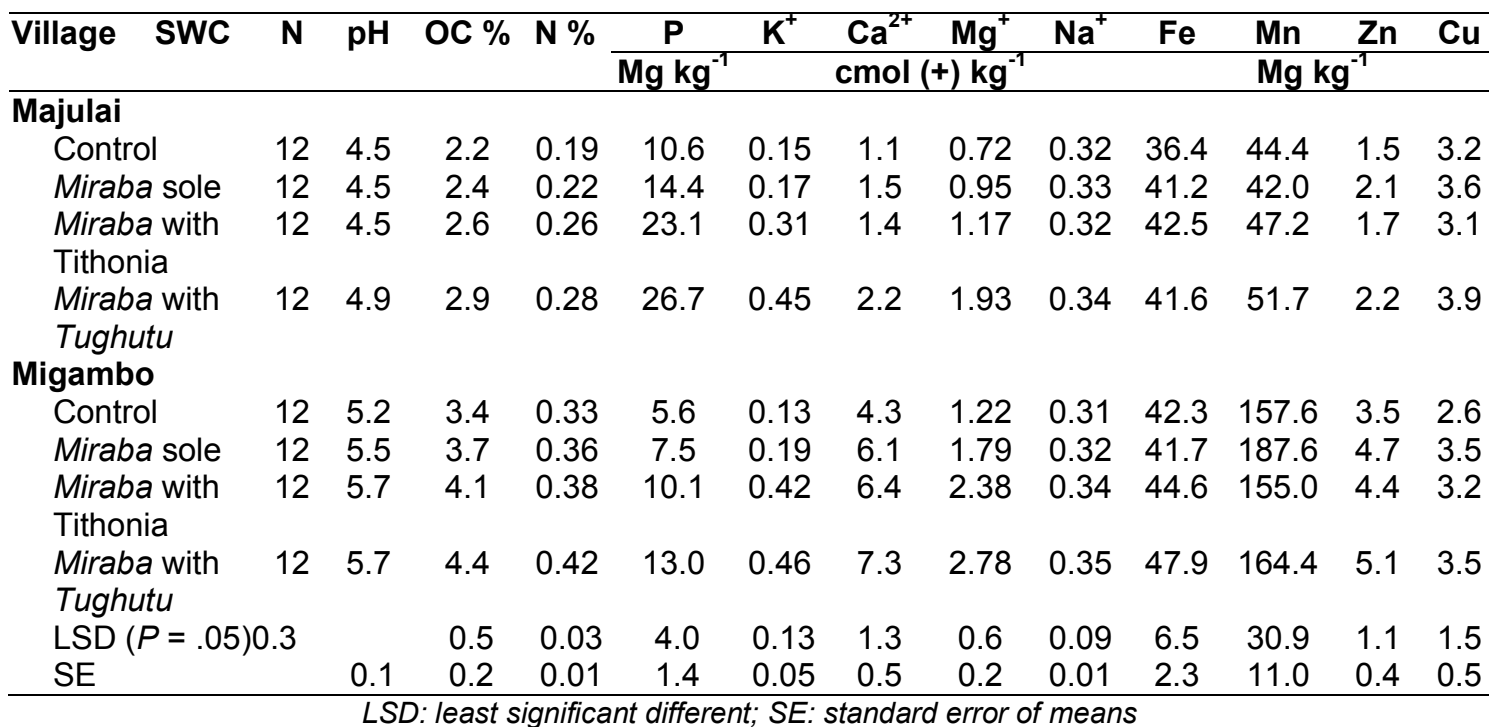


The improvements of the aforementioned soil physical and chemical properties under miraba can also be explained by the fact that, apart from the ability of grass barriers forming miraba of retaining soil sediments and nutrients, miraba were also progressively forming bench terraces such that the terrace height was raised to about $1 \mathrm{~m}$ in Migambo and $0.7 \mathrm{~m}$ in Majulai village after three years of experimentation. The terraces so formed cut down the slope steepness resulting reduced runoff velocity and increased rate of infiltration which in turn reduced runoff volume thus reducing soil and nutrient losses. Observations by Gilley et al. [27] reported grass hedge to effectively reduce runoff and nutrient loads following manure application as compared with cropland with no grass hedge. A similar observation was madeby Wanyama et al. [28] who reported elephant grass, lemon grass, paspalum and sugarcane to effectively trap sediments and reduce runoff from cropland in Uganda.

\subsection{The Influence of Selected SWC Practices on Crop Yields in Majulai and Migambo Villages}

Maize and bean yields under the studied SWC practices in the Majulai and Migambo villages are presented in Table 4. Significant $(P=.05)$ differences in crop yields between SWC practices were observed. Maize and bean grain yields followed the trend: miraba with Tughutu > miraba with Tithonia > miraba sole > control in both villages (Table 4). Maize grain yields were significantly $(P=.05)$ higher in 2013 than in 2012, but there were no significant $(P=.05)$ differences in bean grain yields between the two years of study. It was clearly observed that crop yield differences between treatments were highly influenced by the SWC practices (Table 4), while the higher crop yields under miraba with Tithonia and miraba with Tughutu mulches could be explained by the improved soil properties especially of AMC, OC, $\mathrm{N}, \mathrm{P}, \mathrm{K}, \mathrm{Ca}^{2+}, \mathrm{Mg}^{2+}, \mathrm{pH}$ and $\mathrm{BD}$ (Tables $2 \& 3$ ). Similar observations were reported by Tenge [9] where Fanya Juu terraces had significantly higher maize and bean yields than under bench terraces and grass strips while control was the least; likewise the study by Msita [10] found miraba with farmyard manure and mulching to have higher maize and bean yields than miraba sole and control had the least. The higher yields were associated with improved soil fertility. The observed crop yields under the studied SWC practices (Table 4) were higher than the average yields according to FAO [29] of $1.5 \mathrm{Mg} \mathrm{ha}{ }^{-1}$ for maize and of $0.7 \mathrm{Mg} \mathrm{ha}^{-1}$ for beans in Tanzania.

When considering variability of crop yields within the studied SWC practices, it can be seen from Table 4 that, crop gra in yields did not significantly $(P=.05)$ varied within SWC measures except under cropland with no SWC measures where lower segments had higher maize grain yields than the upper segments. It can easily be noted that maize crop is more sensitive to the effect of gradients than bean crop; this is probably due to the ability of bean to fix nitrogen for its consumption as opposed to maize crop. Tenge [9] reported similar observations where bean crop performance was found not sensitive to slope gradients as opposed to maize. The evenly distributed crop yields within the studied SWC practices can partly be explained by the effect of reducing spacing of grass barriers that form miraba from the traditionally very wide to $5 \mathrm{~m}$ apart.

Table 3. The influence of the studied SWC practices on soil physical properties

\begin{tabular}{llllllll}
\hline Village & SWC practices & N & AMC $\%$ & BD g/cc & Sand \% & Silt \% & Clay \% \\
\hline Majulai & Control & 12 & 23.2 & 0.98 & 34 & 9 & 56 \\
& Miraba sole & 12 & 29.2 & 0.97 & 33 & 9 & 58 \\
& Miraba with Tithonia & 12 & 32.9 & 0.93 & 34 & 9 & 57 \\
\multirow{3}{*}{ Migambo } & Miraba with Tughutu & 12 & 32.9 & 0.91 & 33 & 12 & 55 \\
& Control & 12 & 17.6 & 0.95 & 35 & 13 & 52 \\
& Miraba sole & 12 & 22.7 & 0.89 & 35 & 15 & 51 \\
& Miraba with Tithonia & 12 & 25.9 & 0.88 & 35 & 16 & 50 \\
& Miraba with Tughutu & 12 & 29.3 & 0.83 & 35 & 13 & 52 \\
& LSD $(P=.05)$ & & 3.6 & 0.06 & 5.1 & 3.0 & 4.6 \\
& SE & & 1.3 & 0.02 & 1.8 & 1.1 & 1.6 \\
\hline
\end{tabular}


Table 4. Crop yields under selected SWC practices in Majulai and Migambo villages

\begin{tabular}{|c|c|c|c|c|c|c|}
\hline \multirow[t]{2}{*}{ Village/SWC measures } & \multirow{2}{*}{\multicolumn{2}{|c|}{$\begin{array}{l}\text { Segments with in } \\
\text { SWC measures }\end{array}$}} & \multicolumn{2}{|c|}{$\begin{array}{l}\text { Mean crop grains } \\
\text { yield } \mathrm{Mg} \mathrm{ha}^{-1} \text { in } 2012\end{array}$} & \multicolumn{2}{|c|}{$\begin{array}{l}\text { Mean crop grains yield } \\
\mathrm{Mg} \mathrm{ha}^{-1} \text { in } 2013\end{array}$} \\
\hline & & & Maize & Beans & Maize & Beans \\
\hline \multicolumn{7}{|l|}{ Majulai village } \\
\hline \multirow[t]{3}{*}{ Plots with no SWC } & Upper segment & & 0.51 & 0.56 & & 0.57 \\
\hline & Lower segment & & 0.91 & 0.62 & & 0.61 \\
\hline & Mean & 3 & 0.71 & 0.59 & 0.0 & 0.59 \\
\hline \multirow[t]{3}{*}{ Miraba sole } & Upper segment & & 1.24 & 0.80 & & 0.85 \\
\hline & Lower segment & & 1.28 & 0.82 & & 0.85 \\
\hline & Mean & 3 & 1.26 & 0.81 & 0.0 & 0.85 \\
\hline \multirow[t]{3}{*}{ Miraba with Tithonia } & Upper segment & & 1.61 & 0.89 & & 1.04 \\
\hline & Lower segment & & 1.63 & 0.89 & & 1.04 \\
\hline & Mean & 3 & 1.62 & 0.89 & 0.0 & 1.04 \\
\hline \multirow{3}{*}{ Miraba with Tughutu } & Upper segment & & 1.96 & 0.93 & & 1.09 \\
\hline & Lower segment & & 1.98 & 0.93 & & 1.09 \\
\hline & Mean & 3 & 1.97 & 0.93 & 0.0 & 1.09 \\
\hline $\operatorname{LSD}(P=.05)$ & & & 0.15 & 0.15 & 0.0 & 0.15 \\
\hline SE. & & & 0.05 & 0.05 & & 0.05 \\
\hline \multicolumn{7}{|l|}{ Migambo village } \\
\hline \multirow[t]{3}{*}{ Plots with no SWC } & Upper segment & & 1.07 & 0.62 & 1.33 & 0.65 \\
\hline & Lower segment & & 1.97 & 0.66 & 1.95 & 0.69 \\
\hline & Mean & 3 & 1.57 & 0.64 & 1.64 & 0.67 \\
\hline \multirow{3}{*}{ Miraba sole } & Upper segment & & 2.53 & 0.81 & 3.10 & 0.92 \\
\hline & Lower segment & & 2.63 & 0.81 & 3.14 & 0.92 \\
\hline & Mean & 3 & 2.58 & 0.81 & 3.12 & 0.92 \\
\hline \multirow[t]{3}{*}{ Miraba with Tithonia } & Upper segment & & 3.14 & 0.90 & 4.00 & 1.06 \\
\hline & Lower segment & & 3.22 & 0.90 & 4.10 & 1.06 \\
\hline & Mean & 3 & 3.18 & 0.90 & 4.05 & 1.06 \\
\hline \multirow[t]{3}{*}{ Miraba with Tughutu } & Upper segment & & 3.75 & 0.95 & 4.82 & 1.14 \\
\hline & Lower segment & & 3.83 & 0.95 & 4.84 & 1.14 \\
\hline & Mean & 3 & 3.79 & 0.95 & 4.83 & 1.14 \\
\hline $\operatorname{LSD}(P=.05)$ & & & 0.41 & 0.41 & 0.41 & 0.41 \\
\hline SE. & & & 0.14 & 0.14 & 0.14 & 0.14 \\
\hline
\end{tabular}

LSD: least significant different; SE: standard error of means

This spacing was close enough to limit runoff velocity and thus reduced soil nutrients that could move with it down the slope to the lower segments. Besides, with this spacing, miraba were progressively forming bench terraces which cut down the slope and thus reduce translocation of soil nutrients by runoff. On the other hand mulching was also contributing to the reduced soil nutrient movement from the upper to the lower segments, allowing crops to respond evenly within the studied SWC practices.

\subsection{Relation between Soil Properties and Crop Yields under the Different SWC Measures}

Correlation between soil properties (that discriminated SWC measures) and crop yields are presented in Table 5. It can be seen that all the discriminator soil properties were positively correlated with crop yields except bulk density which was negatively correlated. The negative correlation of bulk density with crop yields can be explained by the fact that, bulk density is greatly influenced by soil organic carbon contents such that low the OC contents high the bulk density of the soils and vice versa (Table $2 \& 3$ ). Similar relationship was also reported by Aticho [26]. Soil OC has been acknowledged to be an important cushion for many soil nutrients, thus the higher the $\mathrm{OC}$ content the higher the soil nutrients in the soil $[23,24]$. A multiple linear regression model was fitted through the discriminate or soil properties that were correlated with crop yields under SWC measures (Table 6). It was found that maize grain yields were significantly $(P=$ $.05)$ a function of $\mathrm{Ca}^{2+}$ and $\mathrm{Mg}^{2+}$ with $\left(\mathrm{R}^{2}=0.85\right)$ under miraba and $\left(R^{2}=0.79\right)$ for crop land with no SW measures. 
Mwango et al.; AIR, 3(6): 558-570, 2015; Article no.AIR.2015.051

Table 5. Soil properties that correlated with crop yields under the studied SWC measures

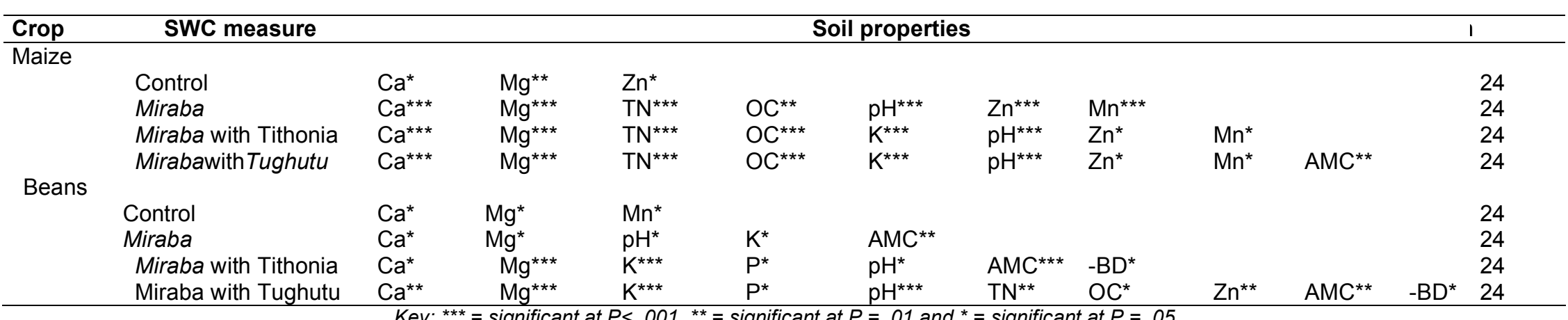


Table 6. Relation between soil properties and crop yields $\left(\mathrm{Mg} \mathrm{ha}^{-1}\right)(\mathrm{Y})$ under the studied SWC measures

\begin{tabular}{|c|c|c|c|c|c|}
\hline Crop & SWC measure & Regression equations & $\mathrm{R}^{2}$ & $P$ & $\mathrm{n}$ \\
\hline \multirow[t]{13}{*}{ Maize } & $\begin{array}{l}\text { Control } \\
\text { Miraba }\end{array}$ & $\mathrm{Y}=0.152+0.104 \mathrm{Ca}^{2+} \mathrm{cmol} / \mathrm{kg}+0.793 \mathrm{Mg}^{2+} \mathrm{cmol} / \mathrm{kg}^{-1}$ & 0.85 & 0.003 & 24 \\
\hline & & $\mathrm{Y}=0.314+0.139 \mathrm{Ca}^{2+} \mathrm{cmol} / \mathrm{kg}+0.038 \mathrm{OC} \%+0.716 \mathrm{Mg}^{2+} \mathrm{cmol} / \mathrm{kg}$ & 0.80 & 0.000 & 24 \\
\hline & & $\mathrm{Y}=0.376+0.03 \mathrm{TN} \%+0.141 \mathrm{Ca}^{2+} \mathrm{cmol} / \mathrm{kg}+0.752 \mathrm{Mg}^{2+} \mathrm{cmol} / \mathrm{kg}$ & 0.80 & 0.000 & 24 \\
\hline & & $\mathrm{Y}=0.381+0.142 \mathrm{Ca}^{2+} \mathrm{cmol} / \mathrm{kg}+0.754 \mathrm{Mg}^{2+} \mathrm{cmol} / \mathrm{kg}$ & 0.79 & 0.000 & 24 \\
\hline & Miraba with Tithonia & & & & \\
\hline & & $\mathrm{Y}=-0.70+5.67 \mathrm{~K}^{+} \mathrm{cmol} / \mathrm{kg}+0.703 \mathrm{Mg}^{2+} \mathrm{cmol} / \mathrm{kg}+0.191 \mathrm{pH}$ & 0.90 & 0.000 & 24 \\
\hline & & $\mathrm{Y}=-0.040+5.62 \mathrm{~K}^{+} \mathrm{cmol} / \mathrm{kg}+0.732 \mathrm{Mg}^{2+} \mathrm{cmol} / \mathrm{kg}+0.85 \mathrm{TN} \%$ & 0.90 & 0.000 & 24 \\
\hline & & $\mathrm{Y}=0.004+5.71 \mathrm{~K}^{+} \mathrm{cmol} / \mathrm{kg}+0.714 \mathrm{Mg}^{2+} \mathrm{cmol} / \mathrm{kg}+0.069 \mathrm{OC} \%$ & 0.90 & 0.000 & 24 \\
\hline & & $\mathrm{Y}=0.134+5.96 \mathrm{~K}^{+} \mathrm{cmol} / \mathrm{kg}+0.762 \mathrm{Mg}^{2+} \mathrm{cmol} / \mathrm{kg}$ & 0.89 & 0.000 & 24 \\
\hline & Miraba with Tughutu & & & & \\
\hline & & $\mathrm{Y}=-1.98+0.0319 \mathrm{AMC} \% \mathrm{vol}+0.848 \mathrm{Mg}^{2+} \mathrm{cmol} / \mathrm{kg}+3.04 \mathrm{~K}^{+} \mathrm{cmol} / \mathrm{kg}+1.63 \mathrm{TN} \%$ & 0.98 & 0.000 & 24 \\
\hline & & $\mathrm{Y}=-2.70+0.0238 \mathrm{AMC} \% \mathrm{vol}+0.313 \mathrm{pH}+0.886 \mathrm{Mg}^{2+} \mathrm{cmol} / \mathrm{kg}+3.35 \mathrm{~K}^{+} \mathrm{cmol} / \mathrm{kg}$ & 0.98 & 0.000 & 24 \\
\hline & & $\mathrm{Y}=-1.37+0.0259 \mathrm{AMC} \%$ vol$+0.970 \mathrm{Mg}^{2+} \mathrm{cmol} / \mathrm{kg}+3.51 \mathrm{~K}^{+} \mathrm{cmol} / \mathrm{kg}$ & 0.97 & 0.000 & 24 \\
\hline \multirow[t]{6}{*}{ Beans } & Control & $\mathrm{Y}=0.456+0.000629 \mathrm{Mn} \mathrm{mg} / \mathrm{kg}+0.0872 \mathrm{Mg}^{2+} \mathrm{cmol} / \mathrm{kg}$ & 0.68 & 0.006 & 24 \\
\hline & & $Y=-1.18+0.0197$ AMC $\%$ vol+0.156 pH & 0.71 & 0.000 & 24 \\
\hline & Miraba with Tithonia & & & & \\
\hline & & $\begin{array}{l}\mathrm{Y}=-0.496+0.0175 \mathrm{AMC} \% \mathrm{vol}+0.00569 \mathrm{P} \mathrm{mg} / \mathrm{kg}+0.0470 \\
\mathrm{Ca}^{2+} \mathrm{cmol} / \mathrm{kg}+0.242 \mathrm{~K}^{+} \mathrm{cmol} / \mathrm{kg}\end{array}$ & 0.89 & 0.000 & 24 \\
\hline & Miraba with Tughutu & & & & \\
\hline & & $\begin{array}{l}\mathrm{Y}=-0.224+0.0123 \mathrm{AMC} \% \mathrm{vol}+0.00839 \mathrm{P} \mathrm{mg} / \mathrm{kg}+0.0474 \\
\mathrm{Ca}^{2+} \mathrm{Cmol} / \mathrm{kg}+0.219 \mathrm{~K}^{+} \mathrm{cmol} / \mathrm{kg}\end{array}$ & 0.90 & 0.000 & 24 \\
\hline
\end{tabular}


However, under miraba with Tithonia mulching maize grain yields werea function of $\mathrm{K}^{+}$and $\mathrm{Mg}^{2+}\left(R^{2}=0.89\right)$, whereas under miraba with Tughutu mulching maize grain yields were a function of $\mathrm{AMC}, \mathrm{K}^{+}$and $\mathrm{Mg}^{2+}\left(\mathrm{R}^{2}=0.97\right)$. Bean grain yields were significantly $(P=.05)$ afunction of $\mathrm{Mg}^{2+}$ and $\mathrm{Mn}\left(\mathrm{R}^{2}=0.68\right)$ under control; AMC and $\mathrm{pH}\left(\mathrm{R}^{2}=0.71\right)$ under miraba; AMC, available $\mathrm{P}, \mathrm{Ca}^{2+}$ and $\mathrm{K}^{+}\left(\mathrm{R}^{2}=0.89\right)$ under miraba with Tithonia mulching; while under miraba with Tughutu mulching bean grain yields were strongly a function of AMC, available $\mathrm{P}, \mathrm{Ca}^{2+}$ and $\mathrm{K}^{+}\left(\mathrm{R}^{2}=0.90\right)$. These observations imply that $\mathrm{AMC}$ and $\mathrm{pH}$ had greater potential of influencing maize and bean grain yields under miraba, while AMC, available $\mathrm{P}$ and $\mathrm{K}^{+}$had greater potential of influencing maize and bean grain yields under miraba with Tithonia and miraba with Tughutu mulching. The enhanced ability of miraba to avail soil water to plants and increase soil pH can be explained by the improved soil OC and exchangeable bases under miraba (Tables 2 \& 3 ). Similar positive correlations of exchangeable bases with $\mathrm{pH}$ and $\mathrm{AMC}$ with $\mathrm{OC}$ were also reported by Mwango [23], Msanya et al. [24] and Shelukindo et al. [30]. The improved $\mathrm{P}$ and $\mathrm{K}^{+}$ were greatly due to the influences of mulching materials applied which have high contents of available $P$ and $K^{+}$(Table 1). This is strongly supported by the findings that applications of organic materials in soils reduce $P$ sorption capacities and increase $P$ availability [31], while also application of high quality organic materials with $P$ content equal to or greater than $3.0 \mathrm{~g} \mathrm{P}$ $\mathrm{kg}^{-1}$ in the soil decreases $\mathrm{P}$ adsorption [32], a tendency that improves $\mathrm{P}$ availability in the soil.

\section{CONCLUSION AND RECOMMENDATIONS}

Most of the studied chemical and physical soil properties were significantly $(P=.05)$ influenced by the studied SWC measures. The trend for total $\mathrm{N}, \mathrm{OC}$, available $\mathrm{P}, \mathrm{Ca}^{2+}, \mathrm{Mg}^{2+}, \mathrm{K}^{+}$and $\mathrm{pH}$ was: miraba with Tughutu > miraba with Tithonia $>$ miraba sole > cropl and with no SWC measures (Control), while $\mathrm{Na}^{+}$did not differ. Micro nutrients $\mathrm{Fe}$ and $\mathrm{Cu}$ did not differ between SWC measures except for $\mathrm{Zn}$ and $\mathrm{Mn}$ which were significantly $(P=.05)$ low in cropl and with no SWC measures. Likewise, miraba with Tughutu mulching had the highest AMC and lowest BD, whereas cropland with no SWC measures had the lowest AMC and highest BD. Maize and bean grain yields differed significantly $(P=.05)$ in the following trend: miraba with
Tughutu > miraba with Tithonia > miraba sole > control in both villages. Crop grain yields did not significantly $(P=.05)$ varied within SWC measures except for control which had higher crop grain yields in the lower segments than the upper segments. AMC and $\mathrm{pH}$ had the greatest potential in influencing maize and bean grain yields under miraba, while AMC, available $\mathrm{P}$ and $\mathrm{K}^{+}$had the greatest potential in influencing maize and bean grain yields under miraba with Tithonia or miraba with Tughutu mulching. Further researches are recommended to investigate the potentials of these mulching materials and their influences for the production of vegetables such as cabbage, tomatoes, onions and carrots which are widely cultivated in the Usambara Mountains.

\section{ACKNOWLEDGEMENTS}

The authors are grateful to the VLIR-UOS supported RIP-DSS SUA Project "Enhancing Indigenous Knowledge on Conservation Agriculture for Poverty Alleviation and Sustainable Livelihood, Usambara Mountains, Lushoto, Tanzania", for providing financial and logistical assistance to the research. The first author is grateful to the Tanzania Commission of Science and Technology (COSTECH) for sponsoring PhD programme that contributed to production of this paper.

\section{COMPETING INTERESTS}

Authors have declared that no competing interests exist.

\section{REFERENCES}

1. Faucette LB, Risse LM, Nearing MA, Gaskin JW, West LT. Runoff, erosion, and nutrient losses from compost and mulch blankets under simulated rainfall. Journal of Soil and Water Conservation. 2004;59:154 -160.

2. Kimaro DN, Poesen J, Msanya BM, Deckers J. Magnitude of soil erosion on the northern slope of the Uluguru Mountsins, Tanzania: Interrill and rill erosion. Catena. 2008;75:38-44.

3. Jiao $P, X u$ D, Wang $S$, Wang $Y$, Liu K, Tang G. Nitrogen loss by surface runoff from different cropping systems. Soil Research. Journal Compilation - CSIRO. 2012;50:58-66.

Available:http://dx.doi.org/10.1071/SR1115 $\underline{2}$ 
4. Vigiak O, Okoba BO, Sterk G, Stroosnijder L. Water erosion assessment using farmers' indicators in the Western Usambara Mountains, Tanzania. CATENA. 2005;64(2-3):307-320.

5. National Bureau of statistics. The population and housing census. Central statistical office of Tanzania, Dar es Salaam; 2012. (Accessed 09/08/2014). Available:http://www.nbs.go.tz/

6. Mowo JG, Janssen $\mathrm{BH}$, Oenema $\mathrm{O}$, German LA, Mrema JP, Shemdoe RS. Soil fertility evaluation and management by smallholder farmer communities in Northern Tanzania. Agriculture, Ecosystems and Environment. 2006;116:47-59.

7. Kyaruzi LA. Relationship between soil and landform derived land qualities and conservation agriculture practices in West Usambara Mountains, Tanzania. MSc. Dissertation Sokoine University of Agriculture. 2013;140.

8. Msita HB, Kimaro DN, Deckers J, Poesen $\mathrm{J}$. Identification and assessment of indigenous soil erosion control measures in the Usambara Mountains, Tanzania. In: 166 Earl T. Nardali (Ed.), No till farming: Effect on soil, pros and cons and potential. Nova Science Publishers, Hauppauge, NewYork. 2010;49-74.

9. Tenge AJM. Participatory appraisal for farm-level soil and water conservation planning in West Usambara highlands, Tanzania. Dissertation for Award of PhD Degree at Wageningen University, Netherlands. 2005;195.

10. Msita HB. Insights into indigenous soil and water conservation technologies in western Usambara Mountains, Tanzania. PhD dissertation $\mathrm{KU}$ Leuven Belgium. 2013;198.

11. Vancampenhout K, Nyssen J, Desta Gebremichael, Deckers J, Poesen J, Mitiku Haile, Moeyersons J. Stone bunds for soil conservation in the Northern Ethiopian highlands: Impacts on soil fertility and crop yield. Soil \& Tillage Research. 2006;90:115.

12. FAO (Food and Agriculture Organization). New_LocClim, Local Climate Estimator software, Agro meteorology group FAO/SDRN, Rome, Italy; 2006.

13. FAO (Food and Agriculture Organization). World reference base for soil resources. A framework for International classification, correlation and communication. World Soil
Resources Reports 106 FAO, Rome, Italy. $2014 ; 182$.

14. Sheng TC. Bench terrace design made simple. Department of Earth Resources Colorado State University Fort Collins, CO 80523, USA. 2002;500 -504.

15. Kaswamila AL. Assessment of the Effectiveness of soil erosion control measures using soil surface micro topographic features in the West Usambara Mountains, Tanzania. International Journal of Marine, Atmospheric \& Earth Sciences. Florida, USA.2013;2327-3356.

16. Shelukindo $H$. Technical recommendations for soil and water conservation measures and agroforestry systems. SECAP and TIP, DALDO, Lushoto; 1995.

17. AHI (African Highlands Initiative). Annual report. District Agricultural Office Lushoto, Tanzania; 2001.

18. Wickama JM, Mowo JG. Indigenous nutrient resources in Tanzania. Managing African Soils. International Institute for Environment and Development, London. 2001;21:1560-3520.

19. Moberg JP. Soil and plant analysis manual. The Royal Veterinary and Agricultural University, Chemistry department, Copenhagen, Denmark. $2001 ; 133$.

20. National Soil Service. Laboratory procedures for routine analysis, $3^{\text {rd }}$ edition. Agricultural Research Institute, Mlingano, Tanga, Tanzania. Miscellaneous. 1990;212.

21. Genstat. Introduction to Genstat 14 for Windows. Statistical service centre, University of Reading, UK. 2011;41.

22. Minitab. Minitab Statistical Software for Quality Improvement. Meet Minitab: Minitab User Guide. Minitab Inc. Pennsylvania State University, USA: 2004;134.

23. Mwango SB. Automated land evaluation for alternative uses in South Western part of Uluguru Mountains, Morogoro rural district, Tanzania. MSc. Dissertation Sokoine University of Agriculture. 2000;182.

24. Msanya BM, Kimaro DN, Kileo EP, Kimbi GG, Mwango SB. Land suitability evaluation for the production of food crops and extensive grazing: A case study of Wami plains in Morogoro rural district, Tanzania. Soils and land resources of Morogoro rural and Urban districts, 
Department of Soil Science, Faculty of Agriculture, Sokoine University of Agriculture, Morogoro, Tanzania. Printed by Mzumbe Book Project, Mzumbe, Tanzania. 2001;1. ISBN 9987605265.

25. Wickama J, Okoba B, Sterk G. Effectiveness of sustainable land management measures in West Usambara highlands, Tanzania. CATENA. 2014;118:91-102.

26. Aticho A. Evaluating organic carbon storage capacity of forest soils. Case study in kafa zone Bita District, South Eastern Ethiopia. American Eurasian Journal of Agriculture and Environmental Sciences. 2013;13(1):95-100.

27. Gilley JE, Durso LM, Eigenberg RA, Marx DB, Woodbury BL. Narrow grass hedge control of nutrient loads following variable manure applications. American Society of Agricultural and Biological Engineers. 2011;54(3):847-855.

28. Wanyama J, Herremans K, Maetens W, Isabirye M, Kahimba F, Kimaro D, Poesen $J$, Deckers J. Effectiveness of tropical grass species as sediment filters in the riparian zone of Lake Victoria. Soil Use and Management. 2012;28:409-418.
29. FAO (Food and Agriculture Organization). Food and Agriculture Organization of the United Nation, 2010 FAOSTAT database, Production: Crops; 2010. (accessed 16/01/2014).

Available:http://faostat.fao.org/site/567/Des ktopDefault.aspx

30. Shelukindo HB, Msanya BM, Semu E, Mwango SB, Singh B, Munishi $P$. Characterization of some typical soils of the miombo woodland ecosystem of kitonga forest reserve, Iringa, Tanzania: Physico-chemical properties and classification. Journal of Agricultural Science and Technology. 2014;A(4):224234.

31. Ikerra ST. Use of minjingu phosphate rock combined with different organic inputs in improving phosphorus availability and maize yields on a chromic acrisol in Morogoro, Tanzania. PhD thesis Sokoine University of Agriculture, Morogoro, Tanzania. 2004;263.

32. Lyamuremye F, Dick RP. Organic materials and phosphorus sorption by soils. Advances in Agronomy. 1996;56:139-185.

(C) 2015 Mwango et al.; This is an Open Access article distributed under the terms of the Creative Commons Attribution License (http://creativecommons.org/licenses/by/4.0), which permits unrestricted use, distribution, and reproduction in any medium, provided the original work is properly cited.

Peer-review history:

The peer review history for this paper can be accessed here: http://www. sciencedomain.org/review-history. php?iid=758\&id=31\&aid=7114 